\title{
Dominasi Pewarisan Pola Sidik Jari Whorl dalam Keluarga Karyawan Fakultas Kedokteran Universitas Muhammadiyah Palembang
}

\section{Dominant Inheritance of Whorl Fingerprint in Staff Families of Medical Faculty Muhammadiyah University Palembang}

\author{
Trisnawati Mundijo, Mitayani Purwoko
}

Laboratorium Biologi Kedokteran Fakultas Kedokteran Universitas Muhammadiyah Palembang

\begin{abstract}
ABSTRAK
Setiap individu memiliki sifat turunan atau sifat warisan dari kedua orangtua. Salah satu sifat yang diwariskan yaitu pola sidik jari. Tujuan penelitian adalah mengetahui bagaimana pewarisan pola sidik jari pada masyarakat kota Palembang khususnya pada karyawan Fakultas Kedokteran Universitas Muhammadiyah Palembang. Penelitian ini berjenis observasional deskriptif dengan desain potong lintang. Sampel penelitian diambil secara keseluruhan dari karyawan yang memenuhi kriteria penelitian sebanyak 22 keluarga sehingga diperoleh 85 orang responden. Hasil penelitian didapatkan bahwa pola sidik jari pada responden adalah whorl (62,3\%), ulnar loop (35,3\%), tented arch (2,2\%), dan radial loop (0,2\%). Pewarisan pola sidik jari dari orang tua ke anak terdiri dari 4 sifat pewarisan yaitu pola sidik jari anak sama dengan pola sidik jari kedua orang tua $(46,4 \%)$, pola sidik jari anak sama persis dengan pola sidik jari ibu $(24,4 \%)$, pola sidik jari anak yang sama persis dengan ayah (14,6\%), serta pola sidik jari anak yang sama hanya dengan salah satu orang tua (14,6\%). Alel yang mengatur pola sidik jari whorl kemungkinan merupakan alel yang bersifat dominan terhadap pola sidik jari lain.
\end{abstract}

Kata Kunci: Dermatoglifi, pola sidik jari, radialloop, tented arch, ulnar loop, whorl

\section{ABSTRACT}

Everybody inherites phenotypes from parents. One of this inherited phenotypes is fingerprint pattern. The aim of this study was to identify the inheritance pattern of fingerprint in Palembang, particularly in Medical Faculty Muhammadiyah Palembang University staff. This study was a descriptive observational study with cross-sectional design. Sample was obtained using total sampling method. Sample size was 22 families with 85 respondents. This study found that the distribution of fingerprint patterns were whorl (62,3\%), ulnar loop (35,3\%), tented arch (2,2\%), and radial loop $(0,2 \%)$. The inheritance of finger print patterns from parents to children were classified into 4 categories: children have exactly the same pattern as their parents (46,6\%), children only have their mother's pattern (24,4\%), children only have their father's pattern (14,6\%), and children only have a part of their parent's pattern (14,6\%). Whorl fingerprint pattern allele(s) may be predominant against other fingerprint pattern alleles.

Keywords: Dermatoglyphics, finger print pattern, radial loop, tented arch, ulnar loop, whorl

Korespondensi: Mitayani Purwoko. Laboratorium Biologi Kedokteran Fakultas Kedokteran Universitas Muhammadiyah Palembang, Jl. K.H. Balqhi (Talang Banten), 13 Ulu, Palembang 30263 Tel. (0711) 520045 Email: mitayani.dr@gmail.com 


\section{PENDAHULUAN}

Dermatoglifi adalah ilmu yang mempelajari tentang sidik jari (pola whorl, loop dan arch), pola sulur pada telapak tangan, serta sudut triradius (1-3). Sidik jari seseorang tidak dapat berubah dan unik untuk setiap individu $(4,5)$. Sidik jari akan menjadi tidak dapat dikenali apabila terjadi pembusukan pada korban tenggelam ataupun korban kebakaran, sehingga diperlukan penanda primer lainnya berupa bentuk gigi-geligi (6). Sidik jari dipengaruhi oleh faktor genetik $(1,7)$ dan faktor lingkungan (1). Proses pembentukan dermatoglifi diperkirakan dipengaruhi oleh faktor genetik secara heterogen sehingga mempengaruhi perbedaan morfologi (1).

Setiap individu memiliki pola sidik jari yang berbeda, meskipun kembar identik (8). Pola sidik jari terdiri dari empat pola, yaitu pola lengkung atau Arch (A), bentuk sosok atau Loop (L) yang terdiri dari left loop dan right loop, serta bentuk lingkaran atau Whorl (W) (9).

Sidik jari dapat dijadikan salah satu cara identifikasi dalam suatu tindakan kriminal $(10,11)$. Selain itu karena memiliki perbedaan antar individu dan dipengaruhi oleh faktor genetik, maka sidik jari juga sangat penting dalam ilmu antropologi, forensik, etnologi, genetika dan kedokteran (11).

Saat ini, penelitian tentang sidik jari masih sangat sedikit (12). Sidik jari manusia merupakan salah satu contoh untuk mengetahui peranan poligen. Penelitian dermatoglifi saat ini lebih fokus untuk melihat gambaran pola sidik jari pada penyakit tertentu (13-15). Hal ini mendorong peneliti untuk mengamati pewarisan pola sidik jari dalam suatu keluarga.

\section{METODE}

Penelitian ini merupakan penelitian deskriptif memakai desain potong lintang. Pengambilan data dilakukan terhadap karyawan Fakultas Kedokteran Universitas Muhammadiyah Palembang dan keluarga intinya pada bulan Oktober-Desember 2016. Sampel diambil secara keseluruhan (total sampling) dengan besar sampel 22 keluarga inti dengan total sampling 85 orang. Kriteria inklusi penelitian ini adalah karyawan yang telah menikah dan memiliki anak. Kriteria eksklusinya adalah karyawan dan atau anggota keluarganya yang memiliki cacat atau kerusakan pada sidik jari. Sebelum dilakukan pengambilan pola sidik jari, jari tangan dibersihkan terlebih dahulu menggunakan air atau alkohol, sehingga pola sidik jari dapat terlihat dengan jelas. Pola sidik jari diperoleh dengan mengoleskan lipstik berwarna merah pada sepuluh jari tangan kemudian jari tangan ditempelkan di atas kertas observasi satu persatu. Pola sidik jari dianalisis oleh 1 orang peneliti dengan alat bantu kaca pembesar (lup).

\section{HASIL}

\section{Distribusi Pola Sidik Jari}

Penelitian ini memperoleh 22 keluarga yang terdiri dari ayah, ibu dan anak kandung yang bersedia menjadi responden. Jumlah total responden dari 22 keluarga tersebut sebanyak 85 orang. Pola sidik jari dihitung berdasarkan jumlah jari tangan sehingga total jari yang diperiksa dalam penelitian ini adalah 850 jari tangan. Distribusi pola sidik jari responden dijabarkan pada Tabel 1.
Dari empat pola sidik jari yang ditemukan, pola sidik jari yang terbanyak adalah pola whorl (62,3\%). Pola sidik jari yang paling sedikit ditemui adalah radial loop $(0,2 \%)$.

Tabel 1. Distribusi pola sidik jari responden

\begin{tabular}{lrr}
\hline \multicolumn{1}{c}{ Pola sidik jari } & $\begin{array}{c}\text { Frekuensi } \\
\text { (jari tangan) }\end{array}$ & Persentase (\%) \\
\hline Radial loop & 2 & 0,2 \\
Ulnar loop & 300 & 35,3 \\
Double loop & 0 & 0 \\
Whorl & 530 & 62,3 \\
Tented arch & 18 & 2,2 \\
Arch & 0 & 0 \\
Total & 850 & 100 \\
\hline
\end{tabular}

\section{Pola Pewarisan dalam Keluarga}

Pewarisan pola sidik jari dari orang tua ke anak terbagi menjadi 4 model pewarisan. Dari hasil penelitian diperoleh 6 orang anak $(14,6 \%)$ memiliki pola yang sama persis dengan ayah, 10 orang anak $(24,4 \%)$ dengan pola yang sama persis dengan ibu, 19 orang anak $(46,4 \%)$ yang berpola sama persis dengan kedua orang tua dan 6 orang anak $(14,6 \%)$ memiliki pola dari salah satu pola ayah atau ibu (Gambar 1).
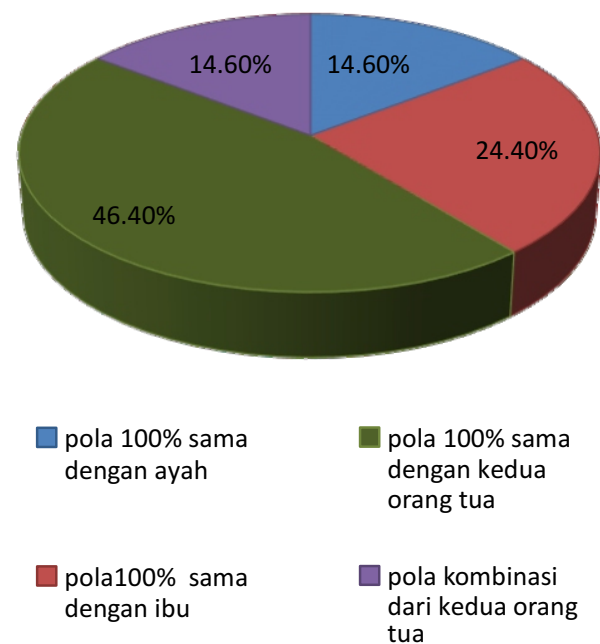

Gambar 1. Distribusi pewarisan pola sidik jari dari orang tua ke anak

\section{DISKUSI}

Pola sidik jari yang paling banyak ditemukan adalah pola whorl $(62,3 \%)$ dan pola yang paling sedikit ditemui adalah radial loop $(0,2 \%)$. Responden yang digunakan dalam penelitian ini berada dalam populasi yang tidak luas sehingga kemungkinan persebaran pola sidik jari tidak dapat dibandingkan dengan populasi yang luas. Para orang tua yang menjadi responden $90 \%$ memiliki pola sidik jari whorl sehingga diturunkan kepada anak-anaknya. Oleh karena itulah pola sidik jari whorl adalah pola yang paling banyak ditemukan dalam penelitian ini. Sementara pada penelitian Sufitni, studi dilakukan pada individu yang bukan anggota keluarga sehingga peluang pola sidik jari lain yang 
Tabel 2. Pola pewarisan sidik jari dalam satu keluarga

\begin{tabular}{|c|c|c|c|}
\hline PARENTAL & WHORL & LAINNYA(O) & Keterangan \\
\hline WHORL & WW & WO & $50 \%$ keturunan akan memiliki pola sidik jari Whorl \\
\hline WHORL & WW & WO & $\begin{array}{l}50 \% \text { keturunan akan memiliki pola sidik jari Whorl dan lainnya (selain } \\
\text { fenotipe whorl) }\end{array}$ \\
\hline \multicolumn{4}{|r|}{ ( } \\
\hline WHORL & WW & WO & $25 \%$ keturunan akan memiliki pola sidik jari Whorl \\
\hline \multirow[t]{2}{*}{ LAINNYA } & Wo & $\mathrm{OO}$ & $\begin{array}{l}50 \% \text { keturunan akan memiliki pola sidik jari Whorl dan lainnya (selain } \\
\text { fenotipe whorl) }\end{array}$ \\
\hline & & & $25 \%$ keturunan akan memiliki pola sidik jari selain whorl \\
\hline PARENTAL & LAINNYA(O) & LAINNYA(O) & \\
\hline WHORL & WO & WO & $100 \%$ keturunan akan memiliki pola sidik jari Whorl dan Other \\
\hline WHORL & WO & WO & \\
\hline \multicolumn{4}{|l|}{ PARENTAL } \\
\hline WHORL & WO & WO & $\begin{array}{l}50 \% \text { keturunan akan memiliki pola sidik jari Whorl dan lainnya (selain } \\
\text { fenotipe whorl) }\end{array}$ \\
\hline LAINNYA & $\mathrm{OO}$ & $\mathrm{OO}$ & $50 \%$ keturunan akan memiliki pola sidik jari selain whorl \\
\hline
\end{tabular}

muncul lebih besar. Hal ini menyebabkan hasil penelitian ini berbeda dengan hasil penelitian Sufitni yang menemukan bahwa pola sidik jari terbanyak pada orang normal adalah ulnar loop $>50 \%$ (16). Hasil penelitian ini memiliki hasil yang sama dengan penelitian Eboh di Nigeria yang mendapatkan pola whorl merupakan pola sidik jari yang terbanyak pada perempuan (5). Pola sidik jari double loop dan arch dalam penelitian ini tidak ditemukan. Hal ini kemungkinan dikarenakan pola tersebut merupakan pola yang jarang ditemukan pada manusia.

Sebanyak 46,4\% dari anak memperoleh pola sidik jari yang sama dengan kedua orang tua masing-masing. Hal ini berarti bahwa suatu sifat termasuk pola sidik jari diturunkan kepada keturunan. Berdasarkan hukum pewarisan sifat Mendel, suatu sifat yang terdapat pada orang tua akan diturunkan kepada anaknya, termasuk pola sidik jari. Sidik jari merupakan fenotipe yang bersifat poligen yaitu sifat yang dikendalikan oleh banyak gen pada lokus yang berbeda dalam kromosom yang sama atau bahkan kromosom yang berbeda (17). Hal inilah yang menyebabkan terjadinya variasi fenotipe dalam sidik jari, sehingga tidak akan ada individu dengan pola yang sama, sehingga setiap individu memiliki keunikan $(4,5)$.

Dalam proses pewarisan pola sidik jari, secara genetik sidik jari pada manusia pada dasarnya adalah ulnar loop. Adanya variasi gen menyebabkan pola dasar tersebut menjadi pola-pola lain yang dipengaruhi oleh beberapa gen.Dalam penelitian ini didapatkan pola pewarisan yang khas yaitu apapun kombinasi pola sidik jari orang tua pasti memiliki pola whorl dan pola whorl ini akan diwariskan kepada anaknya sehingga dapat dikatakan bahwa pola

\section{DAFTAR PUSTAKA}

1. Ho YY, Evans DM, Montgomery GW, et al. Common Genetic Variants Influence on Whorlsin Fingerprint Patterns. Journal of Investigative Dermatology. 2016; 136(4): 859-862.

2. Jindal G, Pandey RK, Gupta S, and Sandhu M. A Comparative Evaluation of Dermatoglyphics in Different Classes of Malocclusion. The Saudi Dental Journal. 2015; 27(2): 88-92.

3. Sontakke BR, Ghosh SK, and Pal AK. Dermatoglyphics of Fingers and Palm in Klinefelter's Syndrome. Nepal whorl adalah fenotipe dominan.

Hukum Mendel I dan II menyatakan bahwa setiap alel akan memisah dan akan berpasangan secara bebas. Pewarisan pola sidik jari yang diperoleh dari penelitian ini dapat disimulasikan dalam persilangan (Tabel 2) menggunakan simbol W untuk pola whorl dan O (other) untuk pola yang lainnya (radial loop, ulnar loop dan tented arch).

Dalam sebuah penelitian di Cina didapatkan semua anak memperoleh pola whorl dari kedua orang tua sehingga kemungkinan gen whorl bersifat dominan terhadap gen lain (18). Etnis responden penelitian ini tidak menjadi variabel penelitian sehingga tidak dilakukan analisis apakah terdapat pengaruh etnis terhadap pewarisan pola sidik jari. Untuk mengetahui peranan etnis dalam pewarisan pola sidik jari perlu dilakukan penelitian pada beberapa kelompok etnis dengan pengambilan data sampai 2 generasi ke bawah, sehingga dapat memberikan gambaran pewarisan antargenerasi dan dalam populasi yang lebih besar. Alel yang mengatur pola sidik jari whorl kemungkinan alel yang bersifat dominan terhadap pola sidikjari lain.

\section{UCAPAN TERIMA KASIH}

Ucapan terima kasih kami sampaikan kepada Dekan Fakultas Kedokteran Universitas Muhammadiyah Palembang atas pemberian izin pengambilan data, Lembaga Penelitian dan Pengabdian Masyarakat Universitas Muhammadiyah Palembang atas pembiayaan penelitian ini berupa hibah internal, serta Rika Riyanti atas bantuannya dalam pengambilan data
Medical College Journal. 2010; 12(3): 142-144.

4. Wijerathne BTB, Rathnayake GK, Adikari SC, Amarasinghe S, Abhayarathna PL, and Jayasena AS. Sexual Dimorphism in Digital Dermatoglyphic Traits among Sinhalese People in Sri Lanka. Journal of Physiological Anthropology. 2013; 32(27): 1-9.

5. Eboh DEO. Fingerprint Patterns in Relation to Gender and Blood Group Among Students of Delta State University, Abraka, Nigeria. Journal of Experimental and Clinical Anatomy. 2013; 12(2): 82-86.

6. Prawestiningtyas E dan Algozi AM. Identifikasi 
Forensik Berdasarkan Pemeriksaan Primer dan Sekunder Sebagai Penentu Identitas Korban pada Dua Kasus Bencana Massal. Jurnal Kedokteran Brawijaya. 2009; 25(2): 87-94.

7. Medland SE, Loesch DZ, Mdzewski B, Zhu G, Montgomery GW, and Martin NG. Linkage Analysis of a Model Quantitative Trait in Humans: Finger Ridge Count Shows Significant Multivariate Linkage to 5q14.1. PloS Genetics. 2007; 3(9): 1736-1744.

8. Beatrice E. Perbandingan Pola Multifaktor Sidik Jari Narapidana di Lembaga Pemasyarakatan Tanjung Gusta Medan dengan Pria Normal di Luar Lembaga Pemasyarakatan. [Skripsi]. Universitas Sumatera Utara, Medan. 2009.

9. Hsieh $\mathrm{CT}$, Shyu SR, dan Hung KM. An Effective Method for Fingerprint Classification. Tamkang Journal of Science and Engineering. 2009; 12(2): 169-182.

10. Thompson MB, Tangen JM, and Duncan DJ. Expertise in Fingerprint Identification. Journal of Forensic Sciences. 2013; 58(6): 1519-1530.

11. Zhang HG, Chen YF, Ding M, et al. Dermatoglyphics from All Chinese Ethnic Groups Reveal Geographic Patterning. PLoS ONE. 2010; 5(1): e8783.

12. Dhall JK and Kapoor AK. Fingerprint Ridge Density as a Potential Forensic Anthropological Tool for Sex
Identification. Journal of Forensic Sciences. 2016; 61(2): 424-429.

13. Sun L, Xue W, Li J, Zhou Z, and Han W. Palm Dermatoglyphs and Interleukin-4 Receptor Polymorphisms in Asthma. Biomedical Reports. 2017; 6 (1): 21-26.

14. Singh E, Saha S, Jagannath GV, Singh S, Saha S, dan Garg N. Association of Dermatoglyphic Peculiarities with Dental Caries in Preschool Children of Lucknow, India. International Journal of Clinical Pediatric Dentistry. 2016; 9(1): 39-44.

15. Lu H, Qian W, Geng Z, et. al. Dermatoglyphs in Coronary Artery Disease Among Ningxia Population of North China. Journal of Clinical and Diagnostic Research. 2015; 9(12): AC01-AC04.

16. Sufitni. Perbandingan Garis Simian dan Pola Sidik Jari Pada Kelompok Retardasi Mental dan Kelompok Normal. Majalah Kedokteran Nusantara. 2007; 40(3): 180-191.

17. Suryo. Genetika Manusia. Yogyakarta: UGM Press; 2010.

18. Yang X, Xiaojun J, Yixuan Z, and Hui L. Genetics Rules for the Dermatoglyphics of Human Fingertips and Their Role in Spouse Selection: A Preliminary Study. Springer Plus. 2016; 5(1): 1396. 